\title{
Emerging Concepts and Practices in Post-Harvest Management of Horticultural Crops Revisited
}

\author{
Mathushika J. M. ${ }^{1}$, Gomes C. ${ }^{2}$ \\ ${ }^{1}$ Department of Plant sciences, Faculty of Science, University of Colombo, Sri Lanka \\ ${ }^{2}$ School of Electrical and Information Engineering, University of Witwatersrand, South Africa
}

\begin{abstract}
This paper offers a comprehensive account on the emerging concepts and practices in post-harvest management of horticultural crops. Post-harvest science and technology facilitates the industries to deliver safe, nutritious and fresh horticultural products to consumers at the end of the supply chain from farm to mouth. Substantial food wastages, which occur in the post-harvest period and such losses, could be reduced by improved post-harvest research, advancement, training and education. At present, many novel technologies and techniques are already being implemented to reduce the post-harvest losses which are witnessed at harvesting, during packing and transportation, in wholesale and retail markets, and during delays at various levels of handling. Improvements are also required to minimize the losses effectively and keep the process-cost low so that it could be applicable at commercial scale in a wide range of economic levels. By developing the practices utilized at post-harvest phase, the expenses accompanying for additional processing paces could also be reduced. Future studies should also be focused on incorporating various emerging technologies with post-harvest practices and appropriate improved practices should be adopted to an existing value chain and marketing system.
\end{abstract}

KEYWORDS: Food Wastages, Marketing System, Post-Harvest Technology, Value Chain

\section{INTRODUCTION}

The State of Food and Agriculture (SOFA) (2019) reports that annually about 1.3 billion metric tons of edible food products in the world are discarded from human consumption due to waste. This loss of food, about one third of the global annual consumable food production accounts to 2.6 trillion USD [1]. This is in a world where about 690 million people are acutely undernourished according to the United Nations (UN) Department of Economic and Social Affairs. In Sri Lanka, food waste is not only a financial issue (loss of edible food), it is also a large-scale social and environmental issue as well [2]. As per several studies conducted in the recent past Sri Lanka generates approximately 7000 tonnes of solid municipality waste per day, out of which about $50 \%-70 \%$ is food waste. If we estimate, $25 \%$ of this waste is due to post-harvest food management issues, the loss comes to about $875-2450$ tonnes per day $[3,4]$.

As per the Sri Lanka Country Brief-2019 of the World Food Program and Global Hunger Index-2020, more than one fifth of the total population cannot afford sufficient foods, which leads to $7.6 \%$ of the population suffer from under nutrition. Thus, it is a prime need of the country to save at least a part of the food that goes into waste, rather than looking for converting waste to useful materials after letting the food products to be wasted. Post-harvest food management technologies play a vital role in this context. Post-harvest technology is an interdisciplinary "Science and Technique" used for the safety, preservation, refining, packaging, distribution, marketing and use of agricultural products after harvest in order to fulfil the food and nutritional demands of the community [5]. The significance of post-harvest technology focuses to satisfy the food requirements of the rising population through minimizing losses and producing more nutritious food items from raw commodities by proper processing [6,7].

Losses of horticultural produce are a key issue in the post-harvest process [8, 9]. These losses are driven by wide range of variables, ranging from growing conditions to retail handling. Losses do not reflect only by food waste, but a similar waste of human energy, farm inputs, livelihoods and capital. Inefficiencies in the food processing chain and the resultant waste have a solid adverse effect on the food supply, environment and productivity. Thus, the avoidance and elimination of food losses is not just an objective linked to food security itself. This is particularly important in the case of emerging economies where the food processing and post-harvest technologies are still excessively energy intensive [10, 11]. Most often such energy intensive technologies become a burden to both 


\section{International Journal of Current Science Research and Review}

ISSN: 2581-8341

Volume 04 Issue 08 August 2021

DOI: 10.47191/ijcsrr/V4-i8-04, Impact Factor: 5.825

IJCSRR@ 2021

Www.ijcsrr.org

the economy of the country and the local and global environment. Thus, greening the food value chain should go in hands with green energy \& power systems as well.

The origination and systematic use of post-harvest technology involves in intersectional and multidimensional framework, including scientific ingenuity, technical innovation, commercial entrepreneurship, and interdisciplinary research [7]. Thus, in order to minimize post-harvest losses, new technologies should be implemented into post-harvest approaches and, at the same time, research and development should be promoted in the field of post-harvest technology to explore integrated approaches that have a better chance of acceptance and sustainability. Nevertheless, no proper compilation and comprehensive analysis of the recent research improvements and novel technologies in the field of post-harvest technologies. This study is an attempt to accomplish the research void, which will support future improvements and advancements to tackle the prevailing issues in the field of post-harvest technology.

\section{INFORMATION ANALYSIS}

\subsection{Emerging technologies}

Emerging advanced post-harvest technologies will allow all the actors in the perishable supply chain to minimize the losses, assure the optimum quality and extend the shelf life of the fresh produce. The stability of packaging also plays a vital role in this context, where package industry is forced by the state regulations and the pressure from environmentalists to adopt bio-degradable materials $[12,13]$. Extensive research and development as well as technological innovation in postharvest technologies attempt to conglomerate understanding of plant physiology and technology to maintain optimum quality after harvesting [14]. Optimal postharvest treatments for fresh produce aim to decelerate senescence and maturation processes, reduce/inhibit physiological disorders, and mitigate the risk of pathogen infection and contamination. Along with simple post-harvest temperature control technologies, a broad variety of other techniques have also been generated with the assistance of scientific advancements [15, 16].

\subsubsection{Emerging intelligent packaging technologies}

Intelligent packaging is also well-known as smart packaging. It has the capability to recognize the properties of the food it surrounds or the atmosphere in which it is stored. It is furthermore able to warn the producer, retailer or customer regarding the condition of these food properties [17]. The technology may improve many parameters of the commodity such as food sustainability, food security and safety, quality and reliability of product at user end and during the whole value chain [18]. Intelligent packaging, although uniquely varies from the idea of active packaging, can be utilized to verify the efficacy and integrity of active packaging designs as well [18-20]. A package is described by Yam et al. [21] as "intelligent" if it has the potential of monitoring the product, sensing the atmosphere outside or inside the package, and interacting with the consumer.

Subsequently, the packaging includes sensors that indicate customers that the product is affected and can initiate to reverse the detrimental modifications that have taken place in the commodity [22,23]. These packaging systems include tools that have the potential of detecting and giving data on the utilities and properties of packaged foods [24] and/or supplying an internal or external indicator for the background of the active product and the quality determination of the product [25]. The system becomes smarter with the integration of wireless communication, cloud data resources and data processing units and supportive electronics and components that include data carriers, indicators, and sensors [26, 27].

It is possible to split these system types into three classes.

1. External indicators which are inserted outside the box and which comprise indicators of the temperature, time and physical shock.

2. Internal indicators inside the box - positioned in the package head space or mounted to the lid, such as microbial indicators, oxygen leak indicators, etc. [28].

3. Indicators that improve the effectiveness of the drift of information and efficient contact between the user and the product, including certain unique bar codes that contain information about food items including use and expiry date of consumption. Traceability of the product, anti-counterfeiting, anti-theft and tamperproof devices are also considered in this section [29].

While active packaging requires robust ways of managing oxidation, microbial growth and in-pack humidity, smart packaging models make it easier to monitor and optimize the essential parameters to maintain the quality of food [30]. Examples of modules 


\section{International Journal of Current Science Research and Review}

ISSN: 2581-8341

Volume 04 Issue 08 August 2021

DOI: 10.47191/ijcsrr/V4-i8-04, Impact Factor: 5.825

IJCSRR@ 2021

www.ijcsrr.org

in smart packaging are Time temperature integrators (TTIs), Radio Frequency Identification tags (RFID), ripeness markers, chemical sensors and biosensors. There has been no widespread commercial implementation for most of these smart devices.

\subsubsection{Time temperature integrator (TTI) technology}

A time temperature integrator (TTI) can be viewed as an easy, affordable device that can exhibit a simply observable change that represents the complete or fractional temperature history of a food product to which it is mounted [31,32]. A chemical, mechanical, microbiological or enzymatic irreversible transition, typically conveyed as a noticeable response in the method of mechanical deformation, colour formation or colour change, is the concept of TTI action [33]. It relies on the physical shift or chemical reaction towards temperature and time for chemical or physical responses like acid-base reaction, melting, polymerization, etc. whereas, it is focused on changes in biological function like microorganisms, spores or enzymes, in temperature or time for biological response $[16,35,36]$.

The rate of change depends on the temperature and rises at greater temperatures, similar to the degrading reactions responsible for deteriorating the consistency of the product. Therefore, the TTI's visible response correspondingly describes the time-temperature background of the commodity it goes along with [33]. TTIs should be easily triggered and then demonstrate a shift depending on the reproducible time temperature that is easily measured. This transition must be permanent and preferably imitated or effortlessly connected to the degradation scale and residual shelf-life of the food. Based on their response mechanism, TTIs can be categorized as either partial history or complete history markers [36]. TTIs can be divided into three types [37]:

- Critical Temperature Indicators (CTI) display sensitivity to a reference temperature above (or below). Other important instances where a CTI would be beneficial are denaturation of an essential protein above the critical temperature or development of an infectious agent.

- Critical Temperature/Time Integrators (CTTI) are beneficial in signalling distribution chain disruptions and for products in which quality or safety-relevant changes are triggered or arise at detectable levels above critical temperatures. Microbial growth or enzymatic functions that are restricted below the critical temperature are examples of such reactions.

- Throughout the history of the object, time temperature integrators or indicators (TTI) provide a consistent, temperaturedependent response [38].

Conventional packages act only as food containers, while TTI-based smart packages can accomplish essential functions and also decrease food degradation and shelf-life issues for customers. It is stated that with the advancement of research and utilization of thermo-chromic materials such as nanomaterials, photonic crystals and other new materials, TTI can tackle safety, precision and expense problems and make sure that customers can get reliable and safe food [39, 40]. However, the costs of commercially applicable TTIs are now greater than anticipated and in future, it is important to build a low-cost TTI [26, 31].

In addition to TTIs, many other features included in the intelligent packaging can also be advantageous in numerous ways. Using radio frequency identification (RFID) tags is a ubiquitous technique, which is progressively used in cold chain tracking, supply chain management, and retail [41]. RFID has a number of benefits over older systems such as barcodes and data loggers [42]. RFID saves time and money by reducing manual labour, lowering prices, and enhancing visibility and planning. It also provides access to accurate real-time data, fast product position, the ability to report losses, and the ability to strategically plan product locations [43]. Freshness indicators incorporated into food packaging, such as microbial indicators, leak indicators, spoilage indicators, and ripeness indicators, sense and inform regarding the quality level (exhibiting, ripeness, firmness or freshness level), which in turn reveals the food's safety as well [44]. They are indeed an on-package indicator or sensor that can detect the freshness of food in relation to the environment of the package and provide information about the food's safety and quality [35].

\subsubsection{Temperature controlling techniques}

One of the most significant phases in the post-harvest handling chain is considered to be cooling. Lowering the temperature of fresh produce after harvest significantly decreases the rate of respiration, increases the shelf life and preserves the quality of the produce, while reducing the loss of volume and weight by reducing the rate of water loss and decay [45].

Room cooling: Room cooling is a technique that is comparatively cheap but very slow. Produce is literally placed into a cold space, and the cool air is dispersed around cartons, bags, or bins. This way of cooling is probably more suited to less perishable products 


\section{International Journal of Current Science Research and Review}

ISSN: 2581-8341

Volume 04 Issue 08 August 2021

DOI: 10.47191/ijcsrr/V4-i8-04, Impact Factor: 5.825

IJCSRR@ 2021

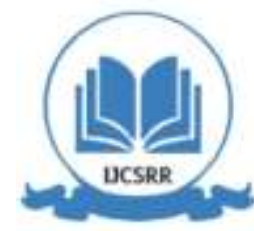

www.ijcsrr.org

including apples, onions, sweet potatoes and citrus fruits, as highly perishable crops would deteriorate before cooling sufficiently. Room cooling may be well suited to chilling sensitive crops that are cooled from relatively cool early morning harvest temperatures to storage temperatures of $10-13^{\circ} \mathrm{C}\left(50-55^{\circ} \mathrm{F}\right)[46]$.

Forced-air cooling: It pushes or draws air through containers of produce, significantly accelerating the cooling rate of any form of product. It is possible to build several categories of forced-air coolers to transfer cold air past the products [47]. Forced-air cooling decreases the cooling time from one or two days in a room cooler to a few hours for a batch of packed produce [48]. If a cold room is available with sufficient cooling space, adding a portable forced-air cooling tunnel that is capable of cooling four pallets at a time would raise the power usage of the fan by only 800 to $1,500 \mathrm{~W} / \mathrm{h}$. A cold room with a cooling capacity of $17.6 \mathrm{~kW}$ (5 tons) will cool $3 \mathrm{MT}$ of horticultural produce in 6 to 8 hours from an initial temperature of $27^{\circ} \mathrm{C}$ to a intended temperature of $2^{\circ} \mathrm{C}$ [49]. Mobile forced air-cooling tunnels and crates are the most beneficial devices. These systems provide the industry with a shorter delivery period and reduce manufacturing costs on site [46].

Hydro-cooling: For some commodities, hydro-cooling provides quick and uniform cooling. The product and its packaging materials must be wet-tolerant, chlorine-tolerant (used to sanitize hydrocooling water), and not prone to damage caused by water-beating [50]. In cooling, hydro-coolers do not loss of moisture and can rehydrate slightly wilted goods. In order to disperse decay species, hydrocooler water must be collected from a sanitary source and chlorinated to reduce the amounts of decay organisms in the water during cooling [51]. Hydro-coolers can be reasonably power effective and are among the minimum costly methods of cooling [46].

Vacuum cooling: Inside a sealed chamber, vacuum cooling requires reducing pressure. Water transforms into vapour within the vegetables, extracting energy from fire. For commodities, those lose moisture rapidly like baby leaf crops and lettuce, vacuum cooling works best. To prevent moisture loss from the product, hydro-vacuum coolers include a misting device. Vacuum cooling is energy efficient and quick [52]. As water transitions from liquid to gas within the vegetables, it absorbs heat energy from the product, cooling it. Approximately $1 \%$ of the output weight needs to be converted into water vapour for every $5^{\circ} \mathrm{C}$ reduction in temperature. Modern hydro-vacuum coolers, however, solve this problem by spraying water during the vacuum process over the produce. This will minimize to marginal levels the loss of moisture [53].

Package icing: Package icing is another basic cooling technique that is used to keep horticultural commodities cool during delivery through the conventional marketing method. Ice is used to lower the temperature of the fresh produce, and crushed ice is manually placed on top of the packaged goods. This approach is useful for short-distance transportation. Top icing and liquid icing are also often used. In top icing, crushed ice is manually or mechanically added to the produce, while ice and water mixtures are pumped into packages through vents or handholds in liquid icing [54].

\subsubsection{Antimicrobial active systems}

Antimicrobial active packaging systems can be classified in to four groups in relation to the mechanism of activity of the antimicrobial compound [55]:

(i) The antimicrobial compound is delivered into the package headspace to communicate with the surface of the goods.

(ii) The antimicrobial compound is introduced into the packaging material and released through a process of migration into the product.

(iii) The antimicrobial agent is immobilised on the package surface.

(iv) The substance in the box has intrinsic antimicrobial activity.

Direct contact between the package and the product is required in groups (iii) and (IV) to achieve the required antimicrobial effect [56].

Headspace artefacts: Headspace artefacts were the first successful antimicrobial packaging to be sold on the market, in the style of sachets covered inside or linked to the container [57]. They can be split into two categories: antimicrobial activity, both indirect and direct. Oxygen and moisture scavengers and carbon dioxide emitters provide headspace artefacts with indirect antimicrobial operation. Since their primary activity is to minimize spoilage due to enzymatic deterioration processes and prevent the development of foggy film, they are called indirect antimicrobials because the change in the internal environment (decrease of oxygen and 


\section{International Journal of Current Science Research and Review}

ISSN: 2581-8341

Volume 04 Issue 08 August 2021

DOI: 10.47191/ijcsrr/V4-i8-04, Impact Factor: 5.825

IJCSRR@ 2021

Www.ijcsrr.org

moisture) prevents the development of aerobic bacteria. Antimicrobial volatile compounds like sulphur dioxide [58], ethanol [59], organic acids and essential oils provide headspace objects with direct antimicrobial activity [60].

Antimicrobial compound incorporated in the package polymer: In order to communicate with the microorganism, another form of antimicrobial active packaging artefacts is in which the antimicrobial compound is incorporated in the bulk polymer and it has to spread to the surface. As carriers, various synthetic and natural polymers have been utilized [61].

Antimicrobial immobilised packages: There are few examples of antimicrobial packages in which ionic or covalent bonds have immobilised the antimicrobial compound into the polymer [55]. The existence of functional groups in both the antimicrobial compound and the polymer is required for the attachment [62]. In order to give the antimicrobial compound more versatility and substantially improve its antimicrobial activity, the existence of a versatile linking group is also preferable [56]. However, available knowledge of the use of this form of packaging in fresh fruits and vegetables has not been published.

Inherently antimicrobial packaging: Some edible biopolymers are intrinsically antimicrobial compounds like chitosan and polyL-lysine, because their positively charged amino groups associate with negative cell membrane charges that facilitate intracellular leaking and, ultimately, cell death [62]. For fresh produce, many biopolymers are being used as edible coating treatments. Chitosan has been used actively to avoid fungal degradation of fruits and vegetables as a coating agent. Owing to the presence of calcium chlorite, calcium alginate decreases the development of microorganisms. Their antimicrobial activity has been described, also taking that into account these polymers serve as barriers between the product and the microorganism. Synthetic and semisynthetic intrinsically antimicrobial polymers have been designed for use in various industries like packaging of food [61].

It has been shown that most of the natural antimicrobial active packaging methods already used are effective and design of active packaging as natural antimicrobial delivery systems may be an alternative approach to maintain fresh produce quality and market demand for naturally preserved produce [49].

\subsubsection{Controlled and modified atmosphere}

To improve and strengthen cool storage, controlled atmosphere (CA) and modified atmosphere packaging (MAP) are used. These techniques modify the environment in the surrounding and within the produce, either actively or passively. This affects cellular metabolism, resulting in decrease in catabolism in climacteric fruits and vegetables and inhibition of enzymatic functions [63]. Each product has its own set of ideal CA and MAP conditions, which, in combination with storage time, relative humidity (RH), and ethylene concentration, can affect flavour-life and shelf-life. One of the most appealing features of these techniques is that it is nontoxic and can be used on organic fruits and vegetables [64]. CA and MAP have also benefited from technical advancements. The use of respiratory quotient control has upgraded the managing of both traditional and newly established CA systems; gas scavengers have enhanced the effectiveness of MAP; and the use of natural additives has strengthened food safety throughout the supply chain [63].

CA technology is one of the most innovative postharvest technologies established in the twentieth century [65]. With the advancement of more precise control systems, the CA technique has developed into a dynamic controlled atmosphere (DCA storage). Another non-destructive tool for assessing primary photosynthesis procedures in photosystem II is DCA-CF (Dynamic controlled atmosphere-chlorophyll fluorescence). The fluorescence interactive response monitor (FIRM) sensors, which are capable of detecting fluoresced light, are the most widely used device for DCA-CF [63]. Recently, a novel automated DCA control system based on online real-time Respiratory Quotient (RQ) measurements was established and incorporated into the control unit of CA facility. This allows the CA system to change gas concentrations in real time based on RQ readings, avoiding the noise described earlier because the leakage is factored into the predictive model [66].

MAP is a promising technology that modifies the environment inside the package based on the interaction between the rate of product respiration and the gas transfer through the package [67]. When packaging technology is adjusted to the rate of respiration of the product, an equilibrium modified atmosphere (EMA) can be created in the container, resulting in a reduction in the rate of respiration and metabolic processes, as well as an improvement in product shelf life [68]. Respiration and temperature have a big impact on MAP. BreatheWay ${ }^{\circledR}$ membranes, for example, have thermos sensitive crystalline polymers that enable high gas 


\section{International Journal of Current Science Research and Review}

ISSN: 2581-8341

Volume 04 Issue 08 August 2021

DOI: 10.47191/ijcsrr/V4-i8-04, Impact Factor: 5.825

IJCSRR@ 2021

www.ijcsrr.org

transmission rates at high temperatures [69]. Research and development should be encouraged to overcome these shortcomings in order to utilize efficient CA and MAP [70].

\subsubsection{Ethylene Controlling Technologies}

In almost every step of plant growth, ethylene is included. Quality parameters linked to taste and aromas have been shown to be controlled by ethylene in fruits. While ethylene is important for the optimal taste and quality of fresh commodities, it can have adverse impacts on the post-harvest life of climatic fruits. As such, it is commonly accepted that high levels of ethylene are associated with rapid softening and decreased storage life of climate-specific fruits due to ripening process. Using technologies that are capable of restricting, or eliminating ethylene will minimize the production of ethylene in the fruit environment, thus helping to preserve the quality of climate-changing fruits [71].

Need for the discovery of substitute techniques which have the potential of extracting ethylene has resulted in the production of a novel material, e+® active Ethylene Remover, which has a considerable adsorption ability of ethylene gas. This technique has also shown significant impacts on varieties of non-climacteric fruits such as strawberries. Further research on the technology for fruits, flowers and vegetables is also being carried out globally [72].

The Smart Fresh Quality System is a brand focused on 1-methylcyclopropene (1-MCP). 1methylcyclopropene (1-MCP), a synthetic gaseous compound, has become commercially useful in extending the storability of many plant products [73, 74], and also providing an important tool in research programs attempting to understand and provide new insight into ethylene action and responses [75].1MCP is suspected to bind to ethylene receptors, stopping ethylene from binding and acting. Since 1-MCP has a tenfold higher affinity for receptors than ethylene, it is active at much lower concentrations as compared to ethylene [76]. There are also many other commercial products which can be used as potential chemical alternatives to 1 MCP Silver ions (e.g. silver thiosulfate or silver nitrate) blocks ethylene perception. $\mathrm{CoCl}_{2}$, aminoethoxyvinylglycine (AVG), aminoisobutyric acid (AIB) and aminooxyacetic acid (AOA) are the most widely used ethylene biosynthesis inhibitors [77, 78].

There are a slew of other signals that control ethylene development and perception in plant organs. The involvement of the Nitric Oxide (NO) signal, among the various signalling molecules, is of particular interest because it has now been shown to interact with ethylene effects to directly and considerably affect fruit ripening. NO is a bioactive molecule that can control ethylene production by at least two mechanisms: 1.Direct stoichiometric inhibition 2.Subduing the ethylene biosynthetic enzymes [79]. NO treatment has the capability of extending the shelf life of horticultural commodities and enhancing their preferable characteristics as well [80, 81]. Understanding how NO affects ethylene signalling would provide novel and economically valuable knowledge that could lead to the enhancement of the fruit quality characteristics in future [79].

\subsubsection{Biosensors for pathogen identification}

To make sure safety and quality in the food processing sector in a quick, accurate and simple way, biosensors have been improved as essential alternatives to conventional methods [82]. In several applications like quality control of food components and the identification of microbial and/or chemical ingredients for food protection, biosensors created for the food sector have been utilized [83].

It is important to show fast response to real-time tracking of the target analyte in order to function effectively for a bio sensor. The features of a potential biosensor are that it should be repeatable, reliable and linear. It should not offer false-negative results, and there should be limited false positive outcomes. Perfect biosensors are usually automated systems which should need minimal interaction by the user, have a simple interface, and be low-priced, convenient to use, compact, and portable [83]. Main and sub types of biosensors which are utilized for the detection of foodborne pathogen and their characteristics are summarized in Table 1. 


\section{International Journal of Current Science Research and Review}

ISSN: 2581-8341

Volume 04 Issue 08 August 2021

DOI: 10.47191/ijesrr/V4-i8-04, Impact Factor: 5.825

IJCSRR@ 2021

Www.ijcsrr.org

Table 1: Classification of biosensors and their characteristics

\begin{tabular}{ll}
\hline Types of bio sensors & Sub types of bio sensors \\
\hline Immunosensors & $\begin{array}{l}\text { Enzyme-based } \\
\text { biosensors }\end{array}$ \\
Optical biosensors & $\begin{array}{l}\text { Fluorescence resonance } \\
\text { energy transfer based } \\
\text { biosensors }\end{array}$
\end{tabular}

Surface plasmon resonance biosensors

Colorimetric biosensors

Electrochemical biosensors

Mass-sensitive biosensors

Potentiometric biosensors
Characteristics

Enzyme immobilization is utilized as a foundation for developing biosensor components with characteristics like high reproducibility, storage, sensitivity, stability, quick response and high selectivity. The pathogens can be identified by labelling the antibody with enzymes.

Fluorescence resonance energy transfer (FRET) technology can be used to quantitatively analyze the protein-protein interactions and bio-molecular dynamics between DNA and protein, as well as conformational changes in proteins.

As light is reflected on the inner surface of a material with varying refractive indices, surface plasmon resonance (SPR) occurs and SPR reduces matrix turbidity by calculating the refractive index on the reverse side of the metal film in which the biological selective element is immobilized.

The colorimetric process, which is an appealing optical method, enables the pathogens in the sample to be easily recognized by changing colour.

A universal method of electrochemical detection that is well used for pathogen detection is utilized here and these bio sensors are utilized to analyse electrochemical reactions while continuously monitoring the current shift.

The use of ion-selective electrodes to transform the biological reaction of pathogens into an electrical signal is utilized in potentiometric biosensors.

Impedimetric biosensors Via the microbial metabolism of electrically charged ionic compounds and inert substrates of acidic products like amino acids, lactic acids and acetic acid, impedance biosensors detect pathogens based on variations in environmental conductivity.

Piezoelectric biosensors The piezoelectric sensor's surface is coated with a selective binding agent (e.g. antibodies) in which the solution having bacteria is mounted. As the crystal mass increases, bacteria bind to antibodies that decrease the oscillation frequency.

Magnetoelastic biosensors
The added mass induces a change in the resonance frequency when a target is in contact with the pathogen alloy sensor surface and can be identified remotely by the coil of the signal collector.

[84]

References

[86-88] 


\section{International Journal of Current Science Research and Review}

ISSN: 2581-8341

Volume 04 Issue 08 August 2021

DOI: 10.47191/ijcsrr/V4-i8-04, Impact Factor: 5.825

IJCSRR@ 2021

Www.ijcsrr.org

More sensitive, quicker, compact, equivalent, sensitive and economical biosensors can be built with technological advancements. Additional research work is therefore desired to improve biosensors that can better sense foodborne pathogens and their toxins.

\subsubsection{Nano-technological applications}

Nanotechnology is currently becoming one of the most imperative instruments in the post-harvest production field of modern agriculture. Various biological agents have emerged as economical and efficient candidates for the synthesis of nanoparticles through green synthesis methods, such as microbes (Bacillus spp. Pseudomonas spp. Fusarium spp. Chlorella spp. etc.) and plants/plant extracts (Neem, garlic, aloe, tea etc.). Due to the higher solubility, durability and eco-friendly biodegradability of nanoparticles, they are used in several applications in the food chain of sustainable agro-horticulture [95]. In certain important areas, nanoparticle science will assist us with post-harvest management and shelf life extension of horticultural crops and their products. Nanomaterials can also communicate with food and/or its surrounding area when integrated into polymer matrices, thereby providing the packaging systems with active properties and enhancing food protection and stability [96]. By means of nanotechnology, biodegradable and entirely compostable bioplastic packaging has already been made from organic corn flour [97].

Nano technological advancements allow nano sensors to be used in food packaging to monitor their consistency across the different stages of the logistics process and to ensure the quality of the product to the final customer [98]. Intelligent packaging nanotechnology can assist in providing product features for authentication, monitoring, and location to avoid falsification, adulteration, and avoidance of the variety of goods intended for a particular market. There would be great advantages for the food industry with the intelligent packaging using nano sensors [99].

These nano machines, in the method of small chips undetectable to naked eye, are inserted in food or containers for the use as electronic bar codes that enable food to be tracked at all phases of the process (production, processing, distribution, and consumption) [100]. There is no documentation of any research that expands this monitoring phase until the last stage. Recently modified sensors using nanotechnology and electro catalysis denote a novel and favourable technology for the inexpensive finding of fruit ethylene development that will facilitate future studies in parts where ethylene could not be measured before, due to a shortage of sensitive, compact and near real-time measurement equipment [99]. Furthermore, nanotechnology can also be utilized in antimicrobial packaging systems, comprising an antimicrobial nanoparticle sachet, which diffuses bioactive agents in the packaging or coats bioactive agents on the surface of the packaging content [101].

\subsubsection{Information technologies in post-harvest management}

Through tracking and tracing machineries that encourage food safety and eventually optimize food value chains, smart and improved information technology systems can have a beneficial impact worldwide; via increasing farm multifactor productivity, through developed water logistics and implementation, developed farm operations/processes and optimized machine/fleet maintenance [102]. A framework execution for the monitoring and tracing of agricultural batch products in the food value chain was suggested by Ruiz-Garcia et al. [103] in the agro-food value chain. The suggested model recommends the utilization of web-based data collection, transfer and storage systems that allow networking, accessibility of information in order to achieve maximum traceability [103].

The barcode is one of the most widely distributed tools used for traceability. GS1 is a non-profit organization assigned to the creation and development of global barcode standards to increase the quality and visibility of supply chains by defining products and services. To allow traceability, these GS1 norms can be applied across the food supply chain. In 108 nations, there are GS1 member organisations. Retailers and suppliers of packaged products have used their recognised global trade item numbers (GTINs), such as the SSCC (Serial Shipping Container Code), the EAN (European/International Article Number) and UPC (Universal Commodity Code), for decades. The adoption of GS1 standards differs by country and industry, but has risen exponentially every year, and exertions are being made to improve their adoption by upstream supply chain companies. The GS1 product identification standards form the basis of a foremost initiative commenced by the manufacturing sector to enable traceability back to the farm. The project is known as the "Produce Traceability Initiative" (PTI) and seeks to attain electronic traceability across the supply chain for any product event [102]. In developing countries, , the introduction of greener supply chains, both in terms of logistics and the utilization of eco-friendly technology, will significantly help the growth of sustainable agriculture. 


\section{International Journal of Current Science Research and Review}

ISSN: 2581-8341

Volume 04 Issue 08 August 2021

DOI: 10.47191/ijcsrr/V4-i8-04, Impact Factor: 5.825

\subsubsection{Application of modelling techniques}

Techniques that consist of collecting data from one or more sources and constructing a systematic representation of the data in a model are generally known as modelling techniques. Various modelling techniques are being used in this post-harvest industry to describe numerous processes and to predict various parameters and conditions [104]. Among these, as a consequence of the complexity and efficiency of computers and the accessibility and affordability of modelling techniques, mathematical modelling techniques are currently becoming incredibly widespread as a substitution for costly and complicated experiments of cold chain maintenance in postharvest sector [105]. These various modelling techniques have been created to simulate mass and heat transition, fluid dynamics, and quality variations in and around fresh commodity, based on the complexity [106]. In order to predict the ultimate quality of fresh produce and associated properties, several kinetic, stochastic, deterministic and computer intelligence models have also been developed [107]. Some modelling applications which are currently being used in post-harvest industry are listed below in Table 2

Table 2: Recent modelling applications and their reported uses in post-harvest industry

\begin{tabular}{|c|c|c|}
\hline Modelling applications & Reported uses & References \\
\hline Migration modelling & $\begin{array}{l}\text { Quantifying migration in food packaging systems. Understanding of } \\
\text { migrants from board paper into commodities. }\end{array}$ & {$[108,109]$} \\
\hline $\begin{array}{l}\text { Heat and mass } \\
\text { transfer modelling }\end{array}$ & $\begin{array}{l}\text { Prediction of } \mathrm{CO}_{2}, \mathrm{O}_{2}, \mathrm{~N}_{2} \text {, and } \mathrm{H}_{2} \mathrm{O} \text { concentration and diffusion in } \\
\text { perforation-mediated polymeric packages. }\end{array}$ & {$[110]$} \\
\hline \multirow[t]{2}{*}{ Stochastic modelling } & $\begin{array}{l}\text { Quantifying the effect of ventilation vent on temperature dispersal of } \\
\text { the commodity. }\end{array}$ & \\
\hline & $\begin{array}{l}\text { Evaluation of the quality of perishable food and estimating the } \\
\text { environmental level. } \\
\text { Estimation of the heat production and the cooling effectiveness during } \\
\text { storage and transport. } \\
\text { Development of an Agro-Chain Greenhouse gas emissions calculator } \\
\text { to evaluate the percentage of food losses per chain stage. }\end{array}$ & {$[111,112]$} \\
\hline Kinetic modelling & $\begin{array}{l}\text { Examination of the influence of relative humidity }(\mathrm{RH}) \text { conditions on } \\
\text { the shelf life of commodities including nutritional and sensory qualities. } \\
\text { Studying the kinetics of chemical and sensory alterations taking place } \\
\text { in the period of storage via relating kinetic models. }\end{array}$ & {$[107]$} \\
\hline $\begin{array}{l}\text { Membranegas } \\
\text { Separation } \\
\text { modelling }\end{array}$ & $\begin{array}{l}\text { Studying the impact of external turbulence on the rate of gas } \\
\text { exchange. } \\
\text { Developing a mathematical model for the prediction of the effect of tube } \\
\text { dimension. }\end{array}$ & {$[113]$} \\
\hline
\end{tabular}

\subsection{Recommendations for Future Concerns}

Many studies have shown that approximately $30 \%$ to $40 \%$ of vegetables and fruits are lost before hitting the ultimate customer, and these losses are seen at several post-harvest stages in developing countries [114]. Owing to inadequate temperature control, use of poor quality packets, pathogen contamination, etc., quantity and quality losses occur mainly. Over the past 20 years, less than $5 \%$ of the funding for horticultural study and expansion has been assigned to post-harvest concerns [14]. 


\section{International Journal of Current Science Research and Review}

ISSN: 2581-8341

\section{Volume 04 Issue 08 August 2021}

DOI: 10.47191/ijcsrr/V4-i8-04, Impact Factor: 5.825

When considering Sri Lanka, there are numerous factors and inabilities that contribute to the high rate of post-harvest losses. Due to the generally warm and humid climate of Sri Lanka which is a tropical island, horticultural fresh commodities begin to deteriorate promptly shortly after harvesting. Poverty among farmers and shortage of investment to obtain advanced technology are major roadblocks to reduce post-harvest losses in the local context. Despite the fact that the government has developed many wholesale marketing centres across the country assigned to the effective handling of fresh commodities, most of them are not well equipped to handle fruits and vegetables in the post-harvest phases. The improvement of marketing networks in Sri Lanka has been hampered by a lack of qualified manpower in this field and shortcomings in the agricultural extension service [114].

At the same time, many advanced technologies and practices are being utilized in developed countries in the area of post-harvest management of horticultural commodities such as high power cooling systems, Ultraviolet C (UV-C) light treatment and cold plasma technology. Germicidal and non-ionising artificial ultraviolet C (UV-C) light treatment is used to monitor microbial growth. Some studies show that when this technique is used bioactive compounds are also enhanced. After UV-C treatment, there are no residues left in the commodities, which is a benefit in meeting new market demands [115]. Cold plasma technology is another promising strategy for improving food safety. It is made by passing an electric current through ordinary air or a flame, resulting in reactive gaseous species with antimicrobial properties. It doesn't use any additives, so there aren't any leftovers [116]. Furthermore, food systems of developed nations are often well-organized and developed.

In order to minimize post-harvest losses and ensure the quality of the commodities at the production end, developing countries where higher amount of losses take place at the processing end should also concentrate on research and development in this sector. Capacity-building initiatives undertaken in developing countries in the field of post-harvest technology need to be more widespread and provide technical information on managing research abilities and practices, and also considering consequences of such activities in the natural environment. Governments, Banks and international organisations dedicated to food security should not hesitate to invest in reducing postharvest losses and encouraging research and thus, would be a great upgrade and a step towards raising technology adoption rates and strategies to reducing post-harvest losses. Training and outreach systems for food loss reduction must be introduced worldwide [9].

Therefore, research and advancement in the field of post-harvest technology should be encouraged and the novel researches should focus on the areas including:

- Non-destructive high-speed segregation systems

- New methods of packaging, storage and transport

- Management of pests and diseases for market access

- Regulation of senescence

- Optimisation of supply chain

- Introducing cold chain system

Also, upcoming researches should also concentrate on future success ideas of Post-harvest technology like:

- Awareness of the molecular and genetic basis of quality characteristics like resistance to mechanical stress, resistance to post-harvest diseases and pests

- Integration of accessible techniques (bio-data and nanotechnology) via systems biological approach to resolve food safety and quality issues in the post-harvest stage.

- The enhancement of unique health components in fresh and refined goods.

- Using artificial intelligence and robotics for both personal and mass harvesting, packaging and handling of bulk products.

- Controlling distribution and supply chains effectively.

- Usage of bio-stimulants and/or bio-regulators to monitor efficiency and quality; and to recognize and exploit the underlying metabolic processes that control biochemical and physiological systems that control the degradation of products. 


\section{International Journal of Current Science Research and Review}

ISSN: 2581-8341

Volume 04 Issue 08 August 2021

DOI: 10.47191/ijcsrr/V4-i8-04, Impact Factor: 5.825

IJCSRR@ 2021

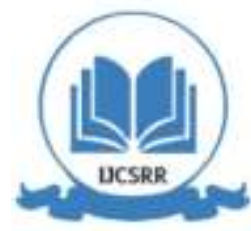

Www.ijcsrr.org

- Integration of renewable energy sources into the energy-intensive post-harvest management operations

- Use of eco-friendly technologies for controlling post-harvest pests and diseases In Sri Lanka, some noteworthy work has been done in reducing the post-harvest losses and improving the storage and shelf-life of agricultural materials in the past decade [117-125]. The National Institute of Post-Harvest Management is pioneering the research in this regard whereas state attention has also been drawn on improving post-harvest product management through the development and implementation of policies and guidelines. However, it is recommended that the scientific approaches should be more focussed on the international technology frontiers, especially in smart and intelligent systems, rather than having a continued attention on improving conventional techniques.

\section{CONCLUSIONS}

In addressing post-harvest losses in the entire concept of greening food value chains, there is a clear need for a more systematic and coherent approach. As mentioned above, post-harvest developments, together with the greening of food value chains, can have a significant effect on food loss avoidance, decline and future recovery of value. It is therefore apparent that policy makers and decision-makers need to take such methodologies into account, particularly as they give massive contribution to improved food security, climate change mitigation and increased employment opportunities.

Developing countries such as Sri Lanka will be the prime beneficiaries in moving towards the frontier technologies and methods of post-harvest management, as a significant fraction of the population in these countries encounter under nutrition and hunger issues.

\section{ACKNOWLEDGEMENTS}

Department of Plant sciences, Faculty of Science, University of Colombo, Sri Lanka and the School of Electrical and Information Engineering, University of Witwatersrand, South Africa are acknowledged.

\section{REFERENCES}

1. SOFA-The state of Food and Agriculture. (2019). How to reduce food loss and waste for food security and environmental sustainability, FAO Agricultural Development Economics, Policy Brief-19.

2. Reitemeier, M.; Aheeyar, M.; Drechsel, P., (2021). Perceptions of Food Waste Reduction in Sri Lanka's Commercial Capital, Colombo. Sustainability 2021, 13, 838. https://doi.org/10.3390/su13020838

3. Karunarathna, A., Singh, R.K., Rajapaksha, T., Premakumara, D.G.J., Onogawa, K. (2019). State of Municipal Solid Waste Management in Negombo City, Sri Lanka; United Nations Environment Program.

4. Sandaruwani, J.A.R.C., Gnanapala, W.K.A.C. (2016). Food wastage and its impacts on sustainable business operations: A study on Sri Lankan tourist hotels. Procedia Food Sci. 2016, 6, 133-135. https://doi.org/10.1016/j.profoo.2016.02.031

5. Han, J.W., Ruiz-Garcia, L., Qian, J.P., Yang, X.T. (2018). Food packaging: a comprehensive review and future trends. Compr Rev Food Sci Food Saf 17:860-877. https://doi.org/10.1111/1541-4337.12343

6. Yahia, E.M. (2008). The role of postharvest technology in improving nutrition and promoting national development in developing countries: Constraints and challenges. In Using Food Science and Technology to Improve Nutrition and Promote National Development; Robertson, G.L., Lupien, J.R., Eds.; International Union of Food Science \&Technology: Toronto, ON, Canada.

7. Stathers, T., Holcroft, D., Kitinoja, L., Mvumi, B., English, A., \& Omotilewa, O. et al. (2020). A scoping review of interventions for crop postharvest loss reduction in sub-Saharan Africa and South Asia. Nature Sustainability, 3(10), 821835. https://doi.org/10.1038/s41893-020-00622-1

8. Kitinoja, L., Barrett, D.M. (2015). Extension of Small-Scale Postharvest Horticulture Technologies - A Model Training and Services Center. Agriculture 5, 441-455. https://doi.org/10.3390/agriculture5030441

9. Kitinoja, L., Saran, S., Roy, S., \& Kader, A. (2011). Postharvest technology for developing countries: challenges and opportunities in research, outreach and advocacy. Journal of the Science of Food and Agriculture, 91(4), 597-603. https://doi.org/10.1002/jsfa.4295 


\section{International Journal of Current Science Research and Review}

ISSN: 2581-8341

Volume 04 Issue 08 August 2021

DOI: 10.47191/ijesrr/V4-i8-04, Impact Factor: 5.825

IJCSRR@ 2021

WWW.ijcsrr.org

10. Stucki M., Blignaut A. (2018) Greening Agri-food Value Chains in Emerging Economies. In: Benetto E., Gericke K., Guiton M. (eds) Designing Sustainable Technologies, Products and Policies. Springer, Cham. https://doi.org/10.1007/9783-319-66981-6_13

11. Hilmi, M. (2019). Green food value chain development: Learning from the bottom of the pyramid, Middle East Journal of Agriculture Research, 8(2): 542-560.

12. Badmus, A. A., Gauri, S., Ali, N. I., and Gomes, C. (2015). Mechanical Stability of Bio based Food Packaging Material, Food Science and Quality Management, Vol.39, pp 41-48, 2015

13. Ncube, L. K., Ude, A. U., Ogunmuyiwa, E. N., Zulkifli, R., Beas I. N. (2020). Environmental Impact of food packaging materials: A review of contemporary development from conventional plastics to polylactic acid based materials, Materials 2020, 13, 4994. https://doi.org/10.3390/ma13214994

14. Mahajan, P., Caleb, O., Singh, Z., Watkins, C., \& Geyer, M. (2014). Postharvest treatments of fresh produce. Philosophical Transactions of the Royal Society A: Mathematical, Physical and Engineering Sciences, 372(2017),

20130309. https://doi.org/10.1098/rsta.2013.0309

15. Qadri, R., Azam, M., Khan, I., Yang, Y., Ejaz, S., Akram, M., \& Khan, M. (2020). Conventional and Modern Technologies for the Management of Post-Harvest Diseases. Sustainability in Plant and Crop Protection, 137-172. https://doi.org/10.1007/978-3-03035955-3_7

16. Manli, Z., Youwei, H., Yi, L., Tirong, R., Hao, L., Junbin, H., Daohong, J., Tom, H., Lu, Z. (2020). Two new biocontrol agents against clubroot caused by Plasmodiophora Brassicae, Frontiers in Microbiology, Front. Microbiol. 10:3099.10.3389/fmicb.2019.03099

17. Sohail. M, Sun D. W., Zhu, Z. (2018). Recent developments in intelligent packaging for enhancing food quality, and safety. Crit Rev Food Sci Nutr 7:1-13. https://doi.org/10.1080/10408398.2018.1449731

18. Chen, S., Brahma, S., Mackay, J., Cao, C., Aliakbarian, B. (2020). The role of smart packaging system in food supply chain, Journal of food science, 85(3), 517-525. https://doi.org/10.1111/1750-3841.15046

19. Hutton, T., 2003: Food packaging: an introduction. 7th edition, Gloucestershire, UK: Campden and Chorley wood Food Research Association Group, 108 p. ISBN 978090594612.

20. Ghaani, M., C. A. G. Castelli, Farris, S. (2016). An overview of the intelligent packaging technologies in the food sector, Trends in Food Science \& Technology, 51, 1-11. https://doi.org/10.1016/j.tifs.2016.02.008.

21. Yam, K., Takhistov, P., \& Miltz, J. (2005). Intelligent Packaging: Concepts and Applications. Journal of Food Science, 70(1), R1-R10. https://doi.org/10.1111/j.13652621.2005.tb09052.x

22. Karel, M., 2000: Tasks of food technology in the 21st century. Food Technology, Vol. 54, p. 56-64. ISSN 0015-6639.

23. Rodrigues, E. T. and Han, J. H., 2003: Intelligent packaging. In: Heldman, D. R. and Moraru, C. I. (Ed.). Encyclopaedia of Agricultural, Food and Biological Engineering. 2nd edition, New York: Marcel Dekker, pp. 528-535. ISBN 9781439811115 .

24. Han, J. H., Ho, C. H. L. and Rodrgue, E. T., 2005: Intelligent packaging. In: Han, J. H. Innovation in Food packaging. UK, London: Elsevier Academic Press, p. 138-155. ISBN 978-0123116321.

25. Ohilsson, T. and Bengsson, N., 2002: Minimal Processing Technologies in the Food Industry. Cambridge, UK: Woodhead Publishing, 288 p. ISBN 978-1855735477.

26. Göransson M, Nilsson F, Jevinger. A (2018) Temperature performance and food shelf-life accuracy in cold food supply chains - insights from multiple field studies. Food Control 86:332-341. https://doi.org/10.1016/j.foodcont.2017.10.029

27. Müller, P., Schmid, M. (2019). Intelligent Packaging in the Food Sector: A Brief Overview. Foods, 8(1), 16. https://doi.org/10.3390/foods8010016

28. Ahvenainen, R., 2003: Novel Food Packaging Techniques. Cambridge UK: Woodhead Publishing, 400 p. ISBN 978-185573-675-7.

29. Coles, R., Mcdowell, D. and Kirwan, M. J., 2003: Food Packaging Technology. Oxford, UK: Blackwell Publishing, 346 p. ISBN 978-0849397882.

30. Kerry, J., O’Grady, M., \& Hogan, S. (2006). Past, current and potential utilisation of active and intelligent packaging systems for meat and muscle-based products: A review. Meat Science, 74(1), 113-130. 


\section{International Journal of Current Science Research and Review}

ISSN: 2581-8341

Volume 04 Issue 08 August 2021

DOI: 10.47191/ijesrr/V4-i8-04, Impact Factor: 5.825

IJCSRR@ 2021

WWW.ijcsrr.org

https://doi.org/10.1016/j.meatsci.2006.04.024

31. Albrecht, A., Ibald, R., Raab, V. et al. (2020). Implementation of Time Temperature Indicators to Improve Temperature Monitoring and Support Dynamic Shelf Life in Meat Supply Chains. J Package Technol Res 4, $23-32$. https://doi.org/10.1007/s41783-01900080-x

32. Taoukis, P., \& Labuza, T. (1989). Applicability of Time-Temperature Indicators as Shelf Life Monitors of Food Products. Journal of Food Science, 54(4), 783-788. https://doi.org/10.1111/j.1365-2621.1989.tb07882.x

33. Taoukis, P. S., 2008: Application of Time-Temperature Integrators for Monitoring and Management of Perishable Product Quality in the Cold Chain. In: Kerry, J. and Butler, P. (ed.), 2008: Smart Packaging Technologies for Fast Moving Consumer Goods. John Wiley\&Sons, Ltd., 61-74. ISBN 978-0470028025.

34. Otles, S. and Yalcin, B., 2008: Intelligent food packaging. Log Forum 4, 4, 3.

URL: http://www.logforum.net/vol4/issue4/no3

35. Kuswandi, B., Wicaksono, Y., Jayus, Abdullah, A., Heng, L., \& Ahmad, M. (2011). Smart packaging: sensors for monitoring of food quality and safety. Sensing and Instrumentation for Food Quality and Safety, 5(3-4), 137-146. https://doi.org/10.1007/s11694-011-9120-x

36. Selman, J. D., 1995: Time-temperature indicators. In Rooney, M. L. (ed.), 1995: Active food packaging. 1st edition, London, UK: Blackie Academic \& Professional, pp. 215-237, ISBN 978-0751401912.

37. Taoukis, P. and Labuza, T. P., 2003: Time-temperature indicators (TTIs). In: Ahvenainen, R. (ed.), Novel food packaging techniques. Cambridge, UK: Woodhead Publishing Ltd., 590 p. ISBN 978-0849317897.

38. Pavelková, A. (2013). Time temperature indicators as devices intelligent packaging. Acta Universitatis Agriculturae Et Silviculturae Mendelianae Brunensis, 61(1), 245-251. https://doi.org/10.11118/actaun201361010245

39. Meng, J.J., Qian, J., Jung, S.W., Lee, S.J. (2018). Practicability of TTI application to yogurt quality prediction in plausible scenarios of a distribution system with temperature variations. Food Science and Biotechnology. 2018 Oct; 27(5):13331342. DOI: $10.1007 / \mathrm{s} 10068-0180371-8$.

40. Wang, S., Liu, X., Yang, M., Zhang, Y., Xiang, K., \& Tang, R. (2015). Review of Time Temperature Indicators as Quality Monitors in Food Packaging. Packaging Technology and Science, 28(10), 839-867. https://doi.org/10.1002/pts.2148

41. Ruiz-Garcia, L., \& Lunadei, L. (2011). The role of RFID in agriculture: Applications, limitations and challenges. Computers and Electronics in Agriculture, 79(1), 42-50. https://doi.org/10.1016/j.compag.2011.08.010

42. Kaur, M., Sandhu, M., Mohan, N., \& Sandhu, P. (2011). RFID Technology Principles, Advantages, Limitations \& Its Applications. International Journal of Computer and Electrical Engineering, 151-157.

https://doi.org/10.7763/ijcee.2011.v3.306

43. Kumar, V. (2018). The Role of RFID in Agro-Food Sector. Agricultural Research \& Technology: Open Access Journal, 14(4). https://doi.org/10.19080/artoaj.2018.14.555924

44. Kuswandi, B. (2017). Environmental friendly food nano-packaging. Environmental Chemistry Letters, 15(2), $205-221$. https://doi.org/10.1007/s10311-017-0613-7

45. De, J., Bertoldi, B., Jubair, M., Gutierrez, A., Brecht, J., Sargent, S., \& Schneider, K. (2020). Evaluation and Comparison of Postharvest Cooling Methods on the Microbial Quality and Storage of Florida Peaches. Horttechnology, 30(4), 504-509. https://doi.org/10.21273/horttech04609-20

46. Kitinoja, L., \& F Thompson, J. (2010). Pre-cooling systems for small-scale producers. Stewart Postharvest Review, 6(2), 1-14. https://doi.org/10.2212/spr.2010.2.2

47. Kochhar, V. (2015). Effect of Different Pre-Cooling Methods on the Quality and Shelf Life of Broccoli. Journal of Food Processing \& Technology, 06(03). https://doi.org/10.4172/2157-7110.1000424

48. O’Sullivan, J., Ferrua, M., Love, R., Verboven, P., Nicolaï, B., \& East, A. (2017). Forcedair cooling of polylined horticultural produce: Optimal cooling conditions and package design. Postharvest Biology and Technology, 126, 67-75. https://doi.org/10.1016/j.postharvbio.2016.11.019

49. Carnelossi, M. A., Sena, E. O., Berry, A. D., \& Sargent, S. A. (2019). Effect of Forced-air Cooling, Hydrocooling, or their Combination on Fruit Quality of Two Southern Highbush Blueberry Cultivars. HortScience, 54(1), 136-142. https://doi.org/10.21273/hortsci13181-18 


\section{International Journal of Current Science Research and Review}

ISSN: 2581-8341

Volume 04 Issue 08 August 2021

DOI: 10.47191/ijesrr/V4-i8-04, Impact Factor: 5.825

IJCSRR@ 2021

WWW.ijcsrr.org

50. Toivonen, P. M. (1997). The effects of storage temperature, storage duration, hydro-cooling, and micro-perforated wrap on shelf life of broccoli (Brassica oleracea L., Italica Group). Postharvest Biology and Technology, 10(1), 59-65. https://doi.org/10.1016/s09255214(97)87275-4

51. Cheng, H. (2006). Vacuum cooling combined with hydrocooling and vacuum drying on bamboo shoots. Applied Thermal Engineering, 26(17-18), 2168-2175. https://doi.org/10.1016/j.applthermaleng.2006.04.004

52. Zheng, L., \& Sun, D. (2004). Vacuum cooling for the food industry - a review of recent research advances. Trends in Food Science \& Technology, 15(12), 555-568. https://doi.org/10.1016/j.tifs.2004.09.002

53. Sun, D., \& Zheng, L. (2006). Vacuum cooling technology for the agri-food industry: Past, present and future. Journal of Food Engineering, 77(2), 203-214. https://doi.org/10.1016/j.jfoodeng.2005.06.023

54. Yahia, E., De Jesus Ornelas-Paz, J., \& Elansari, A. (2011). Postharvest technologies to maintain the quality of tropical and subtropical fruits. Postharvest Biology and Technology of Tropical and Subtropical Fruits, 142-195e. https://doi.org/10.1533/9780857093622.142

55. Motelica, L., Ficai, D., Ficai, A., Oprea, O. C., Kaya, D. A., and Andronescu, E. (2020). Biodegradable Antimicrobial Food Packaging: Trends and Perspectives, Foods 2020, 9, 1438; https://doi.org/10.3390/foods9101438

56. Appendini, P., \& Hotchkiss, J. (2002). Review of antimicrobial food packaging. Innovative Food Science \& Emerging Technologies, 3(2), 113-126. https://doi.org/10.1016/s14668564(02)00012-7

57. Boz, Z., Welt, B. A., Brecht, J. K., Pelletier, W., McLamore, E., Kiker, G. A., and Butler, J. E. (2018) Review of Challenges and Advances in Modification of Food Package Headspace Gases," Journal of Applied Packaging Research, 10(1), Article 5 .

58. Ozdemir, M., \& Floros, J. (2004). Active Food Packaging Technologies. Critical Reviews in Food Science and Nutrition, 44(3), 185-193. https://doi.org/10.1080/10408690490441578

59. Vermeiren, L., Devlieghere, F., \& Debevere, J. (2002). Effectiveness of some recent antimicrobial packaging concepts. Food Additives \& Contaminants, 19(sup1), 163-171. https://doi.org/10.1080/02652030110104852

60. Suppakul, P., Miltz, J., Sonneveld, K., \& Bigger, S. (2003). Active Packaging Technologies with an Emphasis on Antimicrobial Packaging and its Applications. Journal of Food Science, 68(2), 408-420. https://doi.org/10.1111/j.13652621.2003.tb05687.x

61. Kenawy, E., Worley, S., \& Broughton, R. (2007). The Chemistry and Applications of Antimicrobial Polymers: A Stateof-the-Art Review. Bio macromolecules, 8(5), 1359-1384. https://doi.org/10.1021/bm061150q

62. López-Rubio, A., Almenar, E., Hernandez-Muñoz, P., Lagarón, J., Catalá, R., \& Gavara, R. (2004). Overview of Active Polymer-Based Packaging Technologies for Food Applications. Food Reviews International, 20(4), 357-387. https://doi.org/10.1081/fri-200033462

63. Falagán, N., \& Terry, L. (2018). Recent Advances in Controlled and Modified Atmosphere of Fresh Produce. Johnson Matthey Technology Review, 62(1), 107-117. https://doi.org/10.1595/205651318x696684

64. Dziedzic, E., Błaszczyk, J., Bieniasz, M., Dziadek, K., \& Kopeć, A. (2020). Effect of modified (MAP) and controlled atmosphere (CA) storage on the quality and bioactive compounds of blue honeysuckle fruits (Lonicera caerulea L.). Scientia Horticulturae, 265, 109226. https://doi.org/10.1016/j.scienta.2020.109226

65. Özer, M., Eris, A., Türk, R., \& Sivritepe, N. (1999). A research on controlled atmosphere storage of kiwifruit. Acta Horticulturae, (485), 293-300. https://doi.org/10.17660/actahortic.1999.485.41

66. Bessemans, N., Verboven, P., Verlinden, B., \& Nicolaï, B. (2016). A novel type of dynamic controlled atmosphere storage based on the respiratory quotient (RQ-DCA). Postharvest Biology and Technology, 115, 91-102. https://doi.org/10.1016/j.postharvbio.2015.12.019

67. Hyun, J., \& Lee, S. (2017). Effect of modified atmosphere packaging on preserving various types of fresh produce. Journal of Food Safety, 38(1). https://doi.org/10.1111/jfs.12376

68. Azene, M., Workneh, T., \& Woldetsadik, K. (2011). Effect of packaging materials and storage environment on postharvest quality of papaya fruit. Journal of Food Science and Technology, 51(6), 1041-1055. https://doi.org/10.1007/s13197-0110607-6 


\section{International Journal of Current Science Research and Review}

ISSN: 2581-8341

Volume 04 Issue 08 August 2021

DOI: 10.47191/ijesrr/V4-i8-04, Impact Factor: 5.825

IJCSRR@ 2021

WWW.ijcsrr.org

69. Clarke, R. (2011). Breatheway® Membrane Technology and Modified AtmospherePackaging. Modified Atmosphere Packaging For Fresh-Cut Fruits And Vegetables, 185208. https://doi.org/10.1002/9780470959145.ch9

70. Parry, R. T. (Ed.). (1993). Principles and Applications of Modified Atmosphere Packaging of Foods. Principles and Applications of Modified Atmosphere Packaging of Foods. Published. https://doi.org/10.1007/978-1-4615-2137-2

71. Arah, I., Amaglo, H., Kumah, E., \& Ofori, H. (2015). Preharvest and Postharvest Factors Affecting the Quality and Shelf Life of Harvested Tomatoes: A Mini Review. International Journal of Agronomy, 2015, 1-6. https://doi.org/10.1155/2015/478041

72. Meyer, M., \& Terry, L. (2010). Manipulating the ripening of imported avocado 'hass' fruit during cold storage using e+® ethylene remover or 1-methylcyclopropene (1-MCP). Acta Horticulturae, (858), 295-300.

https://doi.org/10.17660/actahortic.2010.858.44

73. Blankenship, S., \& Dole, J. (2003). 1-Methylcyclopropene: a review. Postharvest Biology and Technology, 28(1), 1-25. https://doi.org/10.1016/s0925-5214(02)00246-6

74. Watkins, C. (2006). The use of 1-methylcyclopropene (1-MCP) on fruits and vegetables. Biotechnology Advances, 24(4), 389-409. https://doi.org/10.1016/j.biotechadv.2006.01.005

75. Sisler, E., Serek, M., \& Dupille, E. (1996). Comparison of cyclopropene, 1methylcyclopropene, and 3, 3dimethylcyclopropene as ethylene antagonists in plants. Plant Growth Regulation, 18(3), 169-174. https://doi.org/10.1007/bf00024378

76. Tassoni, A. (2006). Inhibition of the ethylene response by 1-MCP in tomato suggests that polyamines are not involved in delaying ripening, but may moderate the rate of ripening or over-ripening. Journal of Experimental Botany, 57(12), 33133325. https://doi.org/10.1093/jxb/er1092

77. Samih, M. (2015). Effects of ethylene inhibitors, silver nitrate (AgNO3), cobalt chloride (CoCl2) and aminooxyacetic acid (AOA), on in vitro shoot induction and rooting of banana (Musa acuminata L.). African Journal of Biotechnology, 14(32), 2510-2516. https://doi.org/10.5897/ajb2015.14788

78. Lima, P., Ribeiro, W., Oliveira, M., Costa, L., \& Finger, F. (2017). Ethylene, 1methylcyclopropene and silver thiosulfate on the post-production of ornamental pepper. Ciência Rural, 47(2). https://doi.org/10.1590/0103-8478cr20151611

79. Manjunatha, G., Gupta, K., Lokesh, V., Mur, L., \& Neelwarne, B. (2012). Nitric oxide counters ethylene effects on ripening fruits. Plant Signaling \& Behavior, 7(4), 476-483. https://doi.org/10.4161/psb.19523

80. Cheng, G., Yang, E., Lu, W., Jia, Y., Jiang, Y., \& Duan, X. (2009). Effect of Nitric Oxide on Ethylene Synthesis and Softening of Banana Fruit Slice during Ripening. Journal of Agricultural and Food Chemistry, 57(13), 5799-5804. https://doi.org/10.1021/jf901173n

81. Zhu, S., Sun, L., \& Zhou, J. (2010). Effects of different nitric oxide application on quality of kiwifruit during $20^{\circ} \mathrm{C}$ storage. International Journal of Food Science \& Technology, 45(2), 245-251. https://doi.org/10.1111/j.1365-2621.2009.02127.x

82. Narsaiah, K., Jha, S., Bhardwaj, R., Sharma, R., \& Kumar, R. (2011). Optical biosensors for food quality and safety assurance - a review. Journal of Food Science and Technology, 49(4), 383-406. https://doi.org/10.1007/s13197-011-04376

83. Thakur, M., \& Ragavan, K. (2012). Biosensors in food processing. Journal of Food Science and Technology, 50(4), 625641. https://doi.org/10.1007/s13197-012-0783-Z

84. Majumdar, T., Chakraborty, R., \& Raychaudhuri, U. (2013). Development of PEI-GA modified antibody based sensor for the detection of S. aureus in food samples. Food Bioscience, 4, 38-45. https://doi.org/10.1016/j.fbio.2013.08.002

85. Soni, D., Ahmad, R., \& Dubey, S. (2018). Biosensor for the detection of Listeria monocytogenes: emerging trends. Critical Reviews in Microbiology, 44(5), 590-608. https://doi.org/10.1080/1040841x.2018.1473331

86. Sharma, H., Agarwal, M., Goswami, M., Sharma, A., Roy, S., Rai, R., \& Murugan, M. (2013). Biosensors: tool for food borne pathogen detection. Veterinary World, 6(12), 968973. https://doi.org/10.14202/vetworld.2013.968-973

87. Meshram, B., Agrawal, A., Adil, S., Ranvir, S., \& Sande, K. (2018). Biosensor and its Application in Food and Dairy Industry: A Review. International Journal of Current Microbiology and Applied Sciences, 7(2), 3305-3324.

https://doi.org/10.20546/ijcmas.2018.702.397 


\section{International Journal of Current Science Research and Review}

ISSN: 2581-8341

Volume 04 Issue 08 August 2021

DOI: 10.47191/ijesrr/V4-i8-04, Impact Factor: 5.825

IJCSRR@ 2021

WWW.ijcsrr.org

88. Mortari, A., \& Lorenzelli, L. (2014). Recent sensing technologies for pathogen detection in milk: A review. Biosensors and Bioelectronics, 60, 8-21. https://doi.org/10.1016/j.bios.2014.03.063

89. Rubab, M., Shahbaz, H., Olaimat, A., \& Oh, D. (2018). Biosensors for rapid and sensitive detection of Staphylococcus aureus in food. Biosensors and Bioelectronics, 105, 49-57. https://doi.org/10.1016/j.bios.2018.01.023

90. Yuan, J., Wu, S., Duan, N., Ma, X., Xia, Y., \& Chen, J. et al. (2014). A sensitive gold nanoparticle-based colorimetric aptasensor for Staphylococcus aureus. Talanta, 127, 163168. https://doi.org/10.1016/j.talanta.2014.04.013

91. Naik, K. (2017). Biosensors in Food Processing - A Review. International Journal of Pure \& Applied Bioscience, 5(4), 1219-1227. https://doi.org/10.18782/2320-7051.5546

92. Fegade, U., Sharma, H., Bondhopadhyay, B., Basu, A., Attarde, S., Singh, N., \& Kuwar, A. (2014). —Turn-on\| fluorescent dipodal chemo-sensor for nano-molar detection of $\mathrm{Zn2+:Application} \mathrm{in} \mathrm{living} \mathrm{cells} \mathrm{imaging.} \mathrm{Talanta,} \mathrm{125,} \mathrm{418-424.}$ https://doi.org/10.1016/j.talanta.2014.03.002

93. Wang, Y., \& Salazar, J. (2015). Culture-Independent Rapid Detection Methods for Bacterial Pathogens and Toxins in Food Matrices. Comprehensive Reviews in Food Science and Food Safety, 15(1), 183-205. https://doi.org/10.1111/15414337.12175

94. Byeon, H., Vodyanoy, V., Oh, J., Kwon, J., \& Park, M. (2015). Lytic Phage-Based Magnetoelastic Biosensors for On-site Detection of Methicillin-Resistant Staphylococcus aureus on Spinach Leaves. Journal of the Electrochemical Society, 162(8), B230-B235. https://doi.org/10.1149/2.0681508jes

95. Dukare, A., Bibwe, B., Bhushan, B., \& Kadam, D. (2016). Nanotechnology in post-harvest horticulture management: a review. National Conference on Trends in Nanobiotechnology. Chaudhary Charan Singh Haryana Agricultural University, Hissar, Haryana. India.

96. Sharma, C., Dhiman, R., Rokana, N., \& Panwar, H. (2017). Nanotechnology: An Untapped Resource for Food Packaging. Frontiers in Microbiology, 8. https://doi.org/10.3389/fmicb.2017.01735

97. Marichelvam, Jawaid, \& Asim. (2019). Corn and Rice Starch-Based Bio-Plastics as Alternative Packaging Materials. Fibers, 7(4), 32. https://doi.org/10.3390/fib7040032

98. Caon, T., Martelli, S., \& Fakhouri, F. (2017). New trends in the food industry: application of nanosensors in food packaging. Nanobiosensors, 773-804. https://doi.org/10.1016/b978-012-804301-1.00018-7

99. Fuertes, G., Soto, I., Vargas, M., Valencia, A., Sabattin, J., \& Carrasco, R. (2016). Nanosensors for a Monitoring System in Intelligent and Active Packaging. Journal of Sensors, 2016, 1-8. https://doi.org/10.1155/2016/7980476

100.Munir, S., Ahmed, S., Ibrahim, M., Khalid, M., \& Ojha, S. (2020). A Spellbinding Interplay between Biological Barcoding and Nanotechnology. Frontiers in Bioengineering and Biotechnology, 8. https://doi.org/10.3389/fbioe.2020.00883

101.Otoni, C., Espitia, P., Avena-Bustillos, R., \& McHugh, T. (2016). Trends in antimicrobial food packaging systems: Emitting sachets and absorbent pads. Food Research International, 83, 60-73.

https://doi.org/10.1016/j.foodres.2016.02.018

102.Denesuk (M.) and Wilkinson (S.) (2011), —Agriculture and Smarter Food Systems\|, The Bridge on Agriculture and Information Technology, 41 (3), Special issue, fall.

103.Ruiz-Garcia, L., Steinberger, G., \& Rothmund, M. (2010). A model and prototype implementation for tracking and tracing agricultural batch products along the food chain. Food Control, 21(2), 112-121. https://doi.org/10.1016/j.foodcont.2008.12.003

104.Onwude, D., Chen, G., Eke-emezie, N., Kabutey, A., Khaled, A., \& Sturm, B. (2020). Recent Advances in Reducing Food Losses in the Supply Chain of Fresh Agricultural Produce. Processes, 8(11), 1431. https://doi.org/10.3390/pr8111431

105.Song, Y., Hu, Q., Wu, Y., Pei, F., Kimatu, B., Su, A., \& Yang, W. (2019). Storage time assessment and shelf-life prediction models for postharvest Agaricus bisporus. LWT, 101, 360-365. https://doi.org/10.1016/j.lwt.2018.11.020

106.Zou, J., \& Li, P. (2020). Modelling of litchi shelf life based on the entropy weight method. Food Packaging and Shelf Life, 25, 100509. https://doi.org/10.1016/j.fps1.2020.100509.

107.Ktenioudaki, A., O’Donnell, C., \& do Nascimento Nunes, M. (2019). Modelling the biochemical and sensory changes of strawberries during storage under diverse relative humidity conditions. Postharvest Biology and Technology, 154, 148158. https://doi.org/10.1016/j.postharvbio.2019.04.023 


\section{International Journal of Current Science Research and Review}

ISSN: 2581-8341

Volume 04 Issue 08 August 2021

DOI: 10.47191/ijesrr/V4-i8-04, Impact Factor: 5.825

IJCSRR@ 2021

WWW.ijcsrr.org

108.Gruyters, W., Verboven, P., Diels, E., Rogge, S., Smeets, B., \& Ramon, H. et al. (2018). Modelling Cooling of Packaged Fruit Using 3D Shape Models. Food and Bioprocess Technology, 11(11), 2008-2020. https://doi.org/10.1007/s11947-0182163-9

109.Fadiji, T., Ambaw, A., Coetzee, C., Berry, T., \& Opara, U. (2018). Application of finite element analysis to predict the mechanical strength of ventilated corrugated paperboard packaging for handling fresh produce. Biosystems Engineering, 174,260-281. https://doi.org/10.1016/j.biosystemseng.2018.07.014

110.Wu, W., \& Defraeye, T. (2018). Identifying heterogeneities in cooling and quality evolution for a pallet of packed fresh fruit by using virtual cold chains. Applied Thermal Engineering, 133, 407-417.

https://doi.org/10.1016/j.applthermaleng.2017.11.049

111.Kim, W., Aung, M., Chang, Y., \& Makatsoris, C. (2015). Freshness Gauge based cold storage management: A method for adjusting temperature and humidity levels for food quality. Food Control, 47, 510-519.

https://doi.org/10.1016/j.foodcont.2014.07.051

112.Broeze, J.; Guo, X.; Axmann, H.; Vollebregt, M. A Systemic Approach for TradeOff Analysis of Food Loss Reduction and Greenhouse Gas Emissions; CCAFS: Wageningen, Netherlands, 2019.

113.Han, J., Qian, J., Zhao, C., Yang, X., \& Fan, B. (2017). Mathematical modelling of cooling efficiency of ventilated packaging: Integral performance evaluation. International Journal of Heat and Mass Transfer, 111,386-397. https://doi.org/10.1016/j.ijheatmasstransfer.2017.04.015

114.Rajapaksha, L., Gunathilake, C., Pathirana, S., \& Fernando, T. (2021). Reducing post-harvest losses in fruits and vegetables for ensuring food security - Case of Sri Lanka. MOJ Food Processing \& Technology, Volume 9(Issue 1 - 2021)

115.Adetuyi, F., Karigidi, K., \& Akintimehin, E. (2020). Effect of postharvest UV-C treatments on the bioactive components, antioxidant and inhibitory properties of clerodendrum volubile leaves. Journal of the Saudi Society of Agricultural Sciences, 19(1), 7-13. https://doi.org/10.1016/j.jssas.2018.03.005

116. Siddique, S., Hardy, G., \& Bayliss, K. (2018). Cold plasma: a potential new method to manage postharvest diseases caused by fungal plant pathogens. Plant Pathology, 67(5), 1011-1021. https://doi.org/10.1111/ppa.12825

117.Perera, M., Kodithuwakku, S.S. and Weerahewa, J., 2011. Analysis of Vegetable Supply Chains of Supermarkets in Sri Lanka. Sri Lankan Journal of Agricultural Economics, 6(1), pp.67-81. DOI: http://doi.org/10.4038/sjae.v6i1.3471

118.Janaka, H. K., Wickramasinghe, P., Vidanarachchi, J. K., Himali, S. M. C., Fernando P. S. (2013). Effect of different packaging materials on quality characteristics of chicken eggs during storage at room temperature in Sri Lanka, 13th ASEAN Food Conference, 9-11 September 2013, Singapore

119.Gunawardhena C.R., Wasala, W.M.C.B., Dissanayake C. A. K., Wijewardana, R.M.N.A., Chandrajith, U.G., Thilakaratne, B.M.K.S. (2014). Use of safe packaging for vegetable transportation on main supply chains in Sri Lanka, International Research Symposium on Post-Harvest Technology, Institute of Post-Harvest Technology, Sri Lanka, 55-59.

120.Karunasena, H.C.P., Senadeera, W., Brown, R.J., Gu, Y.T. (2014). A novel approach for numerical simulation of plant tissue shrinkage during drying, International Research Symposium on Post-Harvest Technology, Institute of Post-Harvest Technology, Sri Lanka, 55-59.

121.Gunathilake, D., Wasala, W., \& Palipane, K. (2016). Design, Development and Evaluation of a Size Grading Machine for Onion. Procedia Food Science, 6, 103-107. https://doi.org/10.1016/j.profoo.2016.02.022

122.Gunathilake, D.C., \& K. Tiwari, A. (2017). Evaluation of Efficacy of Washing Treatment for Extending the Post-Harvest Life of Tomato (Solanum lycopersicum L). International Journal of Current Microbiology and Applied Sciences, 6(11), 1999-2004. https://doi.org/10.20546/ijcmas.2017.611.238

123.Samaradiwakara, S., Champa, W., \& Eeswara, J. (2019). Harvest maturity affects postharvest quality of lime fruits (<em>Citrus aurantifolia</em> Swingle). Tropical Agricultural Research, 30(4), 125. https://doi.org/10.4038/tar.v30i4.8334

124.Dharmathilake, N., Rosairo, H., Ayoni, V., \& Herath, R. (2020). Implications of Post-Harvest Losses and Acreage Response of Selected Up-Country Vegetables from Nuwara-Eliya District in Sri Lanka on Sustained Food Security. Journal of Agricultural Sciences - Sri Lanka, 15(1), 88. https://doi.org/10.4038/jas.v15i1.8674 


\section{International Journal of Current Science Research and Review}

ISSN: 2581-8341

Volume 04 Issue 08 August 2021

DOI: 10.47191/ijesrr/V4-i8-04, Impact Factor: 5.825

IJCSRR@ 2021

WwW.ijcsrr.org

125. Mohamed, A., Wathugala, D., Indika A., and Samaraweera, G. C. (2020) Conference: International Symposium on Agriculture and Environment -ISAE 2020, Meeting Future Food Demands: Security \& Sustainability, Faculty of Agriculture, University of Ruhuna, Matara, Sri Lanka.

Cite this Article: Mathushika J. M., Gomes C. (2021). Emerging Concepts and Practices in Post-Harvest Management of Horticultural Crops Revisited. International Journal of Current Science Research and Review, 4(8), 859-876 